\title{
Evolution of drainage system morphology at a land-terminating Greenlandic outlet glacier
}

\author{
Tom Cowton, ${ }^{1}$ Peter Nienow, ${ }^{1}$ Andrew Sole, ${ }^{1,2}$ Jemma Wadham, ${ }^{3}$ Greg Lis, ${ }^{3}$ \\ Ian Bartholomew, ${ }^{1}$ Doug Mair, ${ }^{4}$ and Dave Chandler ${ }^{3}$ \\ Received 28 June 2012; revised 22 October 2012; accepted 1 November 2012.
}

[1] The influence of meltwater on the dynamics and geomorphic impact of the Greenland Ice Sheet is strongly controlled by the morphology of the ice sheet's drainage system. However, this system and its evolution through the melt season remain poorly understood. Here we present the results of an intensive programme of dye tracing experiments undertaken along the lower $14 \mathrm{~km}$ of a land-terminating Greenlandic outlet glacier over a period of four months during the 2010 melt season. These data are interpreted in conjunction with observations of proglacial discharge, englacial water storage, surface melt rates and ice velocity to produce a detailed picture of the changing hydrology of the glacier. Following the onset of melt in the spring, inputs to the drainage system regularly exceed outputs, causing the englacial water level to rise to the ice sheet surface. During this time there is a rapid transition from distributed to channelized drainage in those parts of the drainage system closed by ice deformation over winter. As the melt season progresses, channel efficiency increases and englacial storage and ice velocity decrease. High-velocity events continue to be observed following the channelization of the drainage system however, indicating that hydrological forcing of ice velocity occurs despite the existence of channels during periods when meltwater inputs exceed the capacity of the subglacial drainage system.

Citation: Cowton, T., P. Nienow, A. Sole, J. Wadham, G. Lis, I. Bartholomew, D. Mair, and D. Chandler (2013), Evolution of drainage system morphology at a land-terminating Greenlandic outlet glacier, J. Geophys. Res. Earth Surf., 118, doi:10.1029/2012JF002540.

\section{Introduction}

[2] During the summer months, meltwaters drain from the surface to the bed of the Greenland Ice Sheet, flowing to the ice margin along subglacial pathways [Bartholomew et al., 2011b; Das et al., 2008]. Surface meltwaters are thought to drain subglacially for distances of greater than $80 \mathrm{~km}$ [Bartholomew et al., 2011a], and the outflow of water from subglacial drainage systems is observed at numerous locations around the ice sheet margin [Lewis and Smith, 2009]. The subglacial drainage of surface meltwaters is well documented at alpine and polythermal High Arctic glaciers [Bingham et al., 2005; Hubbard and Nienow, 1997], where it is recognized as a critical control on ice dynamics and glacial geomorphology [Iken and Bindschadler, 1986; Swift et al., 2002]. The scale of this process has only been recognized in Greenland during the last decade however [Zwally

\footnotetext{
All Supporting Information may be found in the online version of this article.

${ }^{1}$ School of Geosciences, University of Edinburgh, Edinburgh, UK.

${ }^{2}$ Department of Geography, University of Sheffield, Sheffield, UK.

${ }^{3}$ School of Geographical Sciences, University of Bristol, Bristol, UK.

${ }^{4}$ School of Geosciences, University of Aberdeen, Aberdeen, UK.

Corresponding author: T. Cowton, School of Geosciences, University of Edinburgh, Drummond Street, Edinburgh EH8 9XP, UK. (t.r.cowton@sms.ed.ac.uk)

(C)2012. American Geophysical Union. All Rights Reserved. 2169-9003/13/2012JF002540
}

et al., 2002], and as such there remains much to understand about its implications in an ice sheet context.

[3] One of the key findings from hydrological research at alpine glaciers is that the morphology of the subglacial drainage system evolves in response to changing meltwater inputs over the course of the melt season [Fountain and Walder, 1998; Nienow et al., 1998]. Throughout the winter, drainage occurs through a mostly inefficient, distributed drainage system, such as that characterised by a network of linked cavities [Lliboutry, 1968; Walder and Hallet, 1979]. As the input of meltwater from the glacier surface increases, this forces the formation of a network of efficient subglacial channels [Kamb, 1987; Röthlisberger and Lang, 1987]. The cross-sectional area of these channels then adjusts to accommodate variations in meltwater input as the melt season progresses [Röthlisberger and Lang, 1987].

[4] Understanding this evolution in drainage system morphology is crucial because it controls the relationship between runoff, basal water pressure and, consequently, ice velocity [Kamb, 1987; Schoof, 2010]. As drainage efficiency increases, so greater volumes of water can be transported at lower pressure, preventing a simple correlation between runoff and ice velocity [e.g., Bartholomew et al., 2010; Mair et al., 2002]. Furthermore, when the drainage system is fully adjusted to the input of meltwater (i.e., in a steady-state), water pressure is expected to increase with discharge in a distributed drainage system but decrease with discharge in 
a channelized drainage system [Kamb, 1987; Röthlisberger and Lang, 1987; Schoof, 2010]. As such, knowledge of how the morphology of the drainage system evolves is required to understand and model the relationship between melt and ice velocity in the ablation zone of the ice sheet [Pimentel and Flowers, 2011; Schoof, 2010]. Additionally, drainage system morphology is thought to be a key control on the rate of subglacial erosion [Swift et al., 2002]. The transport of sediments in subglacial channels is highly efficient [Alley et al., 1997], flushing out subglacial debris and thereby exposing fresh bedrock to the erosive power of the ice [Collins, 1979; Swift et al., 2002]. Knowledge of drainage system configuration is therefore also critical for assessing the geomorphic impacts of ice masses.

[5] In recent years, the alpine model of drainage system evolution has been increasingly employed to explain observations of glaciological processes in Greenland. In particular, the debate over the stability of land-terminating sectors of the ice sheet has focussed on whether increasing runoff is offset by increasing drainage efficiency, allowing subglacial water pressure, and hence ice velocity, to remain stable or even fall in a warming climate [Bartholomew et al., 2010, 2011a; Sundal et al., 2011; van de Wal et al., 2008]. The existence of efficient subglacial channels has also been invoked to explain the rapidity of erosion beneath the margin of the ice sheet [Cowton et al., 2012]. However, as direct observation of the subglacial drainage system of the ice sheet has not yet been achieved, it is difficult to test these hypotheses and so advance debate in these areas.

[6] Most knowledge concerning the hydrology of the Greenland Ice Sheet comes not from hydrological observation but rather is inferred from observations of ice dynamics. Ice velocities are in general greatest shortly after the onset of melting, then decline as the melt season progresses, indicating an increase in subglacial drainage efficiency in response to rising melt inputs [Bartholomew et al., 2010, 2011a; Hoffman et al., 2011; Sundal et al., 2011]. Some support for this interpretation has been gained through the study of meltwaters draining from the Greenland Ice Sheet [Bartholomew et al., 2011b; Bhatia et al., 2011]. Variation in the discharge, electrical conductivity and sediment load of the proglacial river of Leverett Glacier, a land-terminating outlet glacier in west Greenland, indicated the seasonal expansion of a subglacial hydrological system draining surface meltwaters from an area of over $600 \mathrm{~km}^{2}$ of the ablation zone of the ice sheet [Bartholomew et al., $2011 \mathrm{~b}]$. As the melt rate rose and the volume of meltwater entering this system increased, the extent of the channelized subglacial drainage system appeared to expand at the expense of the distributed system, allowing greater drainage efficiency beneath an increasing area of the ice sheet [Bartholomew et al., 2011b]. However, because the proglacial river integrates meltwater characteristics from the entire catchment, it is difficult from this approach to determine the morphology of the drainage system beneath specific areas of the ice sheet at any time. This is important, as the drainage system morphology is likely to be spatially as well as temporally heterogeneous, comprising a mix of distributed and channelized drainage forms [Fountain, 1993a; Hock et al., 1999; Hubbard et al., 1995; Nienow et al., 1998; Willis et al., 1990]. To improve our understanding of the drainage system of Greenland outlet glaciers, it is therefore necessary to determine drainage system morphology in a more spatially targeted manner.
[7] Here, we present the results of an intensive programme of dye tracing experiments undertaken with the aim of improving our existing understanding of subglacial hydrology inferred from studies of ice dynamics and proglacial hydrology at Leverett Glacier [Bartholomew et al., 2010, 2011a, 2011b, 2012; Cowton et al., 2012]. By flushing dye into a supraglacial stream shortly before it enters a moulin, and monitoring the rate of its emergence at the portal, it is possible to deduce the mean characteristics of the drainage system through which it has passed. This method has played an important role in shaping our understanding of drainage system structure and evolution at alpine and High Arctic glaciers [e.g., Behrens et al., 1975; Bingham et al., 2005; Collins, 1982; Fountain, 1993b; Hock and Hooke, 1993; Hock et al., 1999; Nienow et al., 1998; Seaberg et al., 1988; Willis et al., 1990]. We undertook regular dye tracing experiments from five different moulins located along the lower $14 \mathrm{~km}$ of Leverett Glacier throughout the 2010 melt season in order to examine how the flow of water through the glacial drainage system changes with time and distance from the snout. Through this approach, we aim to provide the most detailed study to date of the structure and evolution of the drainage system in the lower ablation zone of the Greenland Ice Sheet.

\section{Field Site}

[8] Leverett Glacier $\left(67^{\circ} 03^{\prime} \mathrm{N}, 50^{\circ} 07^{\prime} \mathrm{W}\right)$ is a land terminating outlet glacier on the western margin of the Greenland Ice Sheet (Figure 1). The glacier tongue extends $\sim 3.5 \mathrm{~km}$ from the bulk of the ice sheet but catchment modelling from ice surface topography, surface melt rates and proglacial discharge suggests it drains meltwaters from an area of greater than $600 \mathrm{~km}^{2}$, extending over $50 \mathrm{~km}$ from the ice margin [Bartholomew et al., 2011b; Cowton et al., 2012; Palmer et al., 2011]. These meltwaters exit Leverett Glacier from one major portal, located at the northern margin of the glacier terminus. A substantial depression of the ice surface, visible in the field and on topographic maps, indicates the existence of a large subglacial channel extending upglacier from the portal for more than $2 \mathrm{~km}$. While the thermal regime of the glacier has not been studied, it is assumed to be warm-based due to the widespread acceleration of ice velocity observed annually following the onset of the melt season [Bartholomew et al., 2011a; Sundal et al., 2011]. The internal temperature structure is not known, but it is possible that much of the glacier is composed of cold ice, in keeping with other Greenlandic outlet glaciers [Iken et al., 1993].

[9] Work was focussed on five moulins located between 1 and $14 \mathrm{~km}$ from the portal and named L1, L2, L4, L7 and L14 based on their approximate distance upglacier (Figure 1; Table 1). Where several moulins were found in close proximity, the largest was selected for tracer tests. The upglacier extent of this study was limited by the increasing difficulty of access and volume of dye required for tracing experiments at greater distances from the ice margin.

\section{Methods}

\subsection{Temperature and Melt}

[10] Air temperature was monitored throughout the year on Leverett Glacier at a site $2.1 \mathrm{~km}$ upglacier from the terminus at 


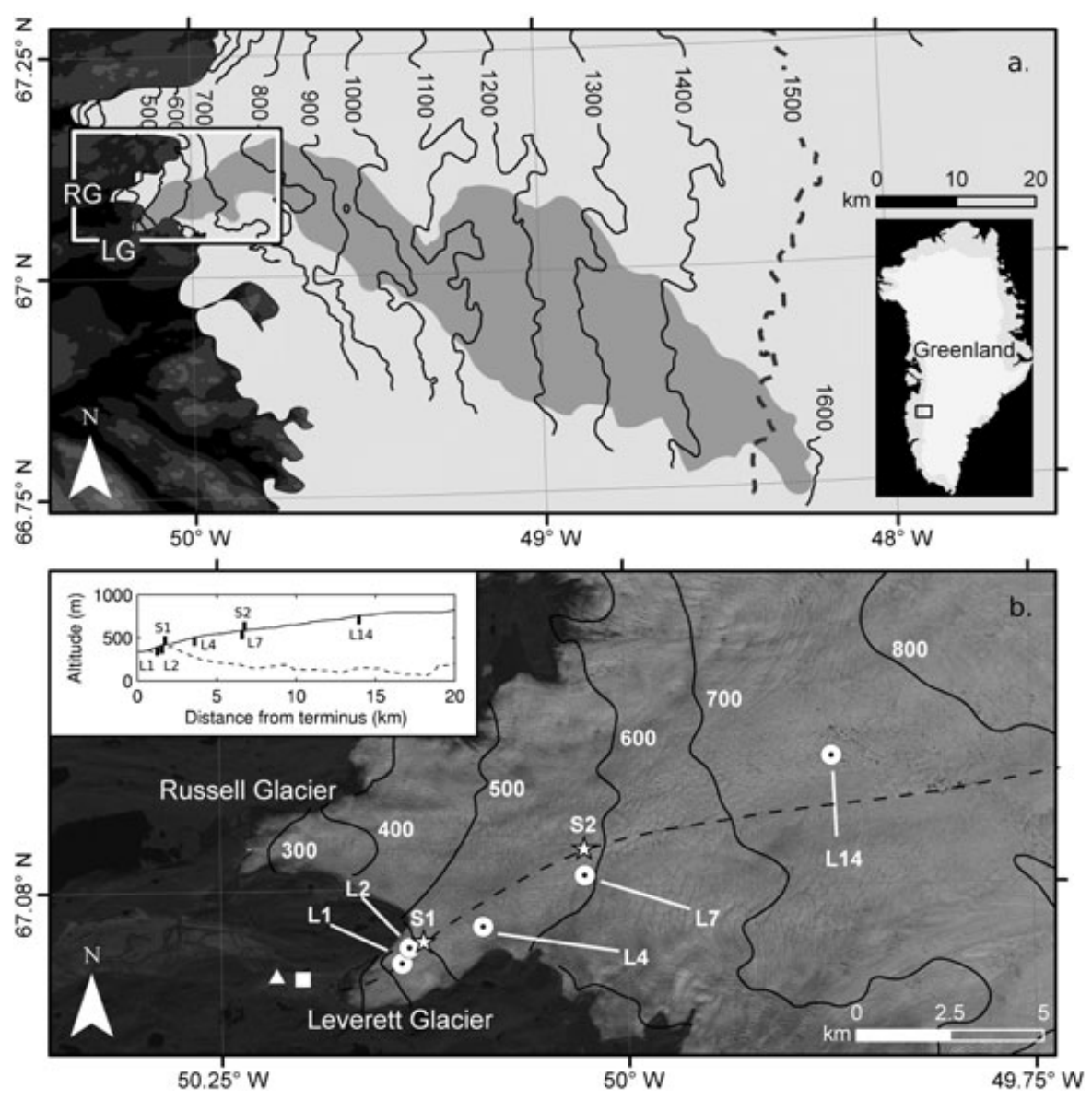

Figure 1. (a) Locations of Leverett hydrological catchment (dark grey shading) as derived from surface digital elevation model (contours in metres) [Palmer et al., 2011]; equilibrium line (dashed) [van de Wal et al., 2008]; Leverett Glacier (LG); and Russell Glacier (RG). Box demarks area expanded below. (b) Landsat ETM+ image of lower ablation zone of Leverett Glacier annotated with ice surface contours in metres; locations of moulins L1-14 (circles); sites S1 (monitoring of air temperature and surface lowering) and S2 (GPS station) (stars); fluorometer (square); gauging site (triangle); and glacier bed and surface elevation profile transect (dashed). Inset shows ice surface (solid line) and bed (dashed line) elevation profiles along this transect [Allen, 2010]. Bars (not to scale) extending below the ice surface indicate the location of moulins L1-14; those extending above the ice surface denote S1 and S2.

Table 1. Locations Referred to in the Text

\begin{tabular}{|c|c|c|c|c|c|c|}
\hline Name & Feature & $\begin{array}{l}\text { Distance From } \\
\text { Portal }(\mathrm{km})\end{array}$ & Altitude (m) & $\begin{array}{l}\text { Approximate Ice } \\
\text { Thickness (m) }\end{array}$ & $\begin{array}{l}\text { Pressure Transducer } \\
\text { Installed }\end{array}$ & $\begin{array}{l}\text { Pressure Transducer } \\
\text { Last Downloaded }\end{array}$ \\
\hline L1 & Moulin & 1.25 & 385 & 45 & 1 May & 21 August \\
\hline L2 & Moulin & 1.55 & 415 & 45 & - & - \\
\hline L4 & Moulin & 3.60 & 470 & 235 & 25 May & 19 June \\
\hline L7 & Moulin & 6.60 & 560 & 405 & 31 May & 9 June \\
\hline L14 & Moulin & 13.95 & 713 & 700 & - & - \\
\hline $\mathrm{S} 1$ & Temperature / UDG & 2.10 & 450 & 45 & - & - \\
\hline $\mathrm{S} 2$ & GPS & 7.10 & 620 & 415 & - & - \\
\hline
\end{tabular}

$450 \mathrm{~m}$ above sea level (S1, Figure 1). This was achieved using a shielded Campbell Scientific 107 temperature sensor fixed a minimum of $1.5 \mathrm{~m}$ above the ice surface and logged by a Campbell Scientific CR800 datalogger. To measure ablation, a Campbell Scientific SR50A ultrasonic distance gauge (UDG) was fixed to a pole drilled into the glacier at this site which subsequently froze in place. The UDG, in conjunction with a Campbell Scientific CR800 datalogger, measured distance to the ice surface at 1 minute intervals, recording the mean value every 15 minutes. The difference between this distance at midnight on subsequent days was used to give a mean rate of glacier surface lowering for each day of the study period. As snow cover beneath the UDG was negligible (the maximum measured snow depth at this site during the study period was just $0.5 \mathrm{~cm}$ ), no attempt was made to differentiate between snowmelt and icemelt. 


\subsection{Discharge}

[11] Stage was recorded at a stable bedrock section located $\sim 2.2 \mathrm{~km}$ downstream of the portal (Figure 1), using a Druck pressure transducer in conjunction with a Campbell Scientific CR1000 datalogger. Monitoring commenced on 6 May and terminated on 27 August 2010. Stage was converted to bulk discharge using a relationship derived from 29 dye dilution gauging experiments undertaken across the full range of stages. Uncertainty in the discharge values is estimated at $\pm 15 \%$ [see auxiliary material of Cowton et al., 2012].

\subsection{Moulin Water Levels}

[12] Englacial water level was recorded at L1, L4, and L7 using Onset HOBO pressure transducers suspended on fixed lengths of cord (Table 1). The depth at which the pressure transducer could be suspended was in each case limited by the shape of the moulin, and was fixed at $-13 \mathrm{~m}$ at L1 and $-38 \mathrm{~m}$ at L4 (relative to the ice sheet surface at the upglacier lip of the moulin). The depth of the pressure transducer within L7 could not be established because of the complex shape of this moulin. Because all three pressure transducers were fixed relatively close to the ice surface, water level could only be measured at times when the englacial water level was high. The pressure transducers at L4 and L7 became frozen in during June, hence the water level records from these moulins are of short duration relative to that at L1 (Table 1).

\subsection{Dye Tracing}

[13] Between 2 May and 19 August 2010, 43 successful dye tracing experiments were undertaken on Leverett Glacier (see auxiliary material) during the period of peak daily supraglacial runoff ( $1100 \mathrm{~h}$ to $1800 \mathrm{~h})$. Snow cover is limited on this lower $14 \mathrm{~km}$ of Leverett Glacier, with a premelt season snow depth of just $3 \mathrm{~cm}$ recorded in the vicinity of L14 on 27 April. Snow remained in some hollows at the time of the first experiment (L1, 2 May), but was otherwise absent at the time and location of dye injections. For each experiment, a known quantity of rhodamine-B or rhodamine-WT dye was flushed into the supraglacial stream immediately upstream of a moulin. Emergent dye was then monitored using a Turner Designs CYCLOPS-7 Submersible Fluorometer in conjunction with a Campbell Scientific CR800 datalogger, located in the proglacial river $\sim 1.5 \mathrm{~km}$ downstream of the portal (Figure 1). This site was selected as it provided a stable and accessible section of bedrock riverbank on which to attach the fluorometer. Fluorescence was sampled every 5 seconds, with mean values stored at 1 minute intervals. These were then converted to dye concentration based on field calibration of the fluorometer to produce dye breakthrough curves for each experiment, which were filtered to remove high-frequency signal noise without distorting the phase or form of the curve. These curves were analysed to examine the rate at which dye had passed through the glacier, and the degree and nature of the dispersal of the dye cloud during this passage. To ease comparison, example dye breakthrough curves shown in this paper have been normalized such that their areas are equal, thus removing apparent differences due to the mass of injected dye or the proglacial discharge at the time of detection.

\subsection{Ice Velocity}

[14] Ice motion was monitored throughout the 2010 melt season using a dual-frequency Leica 500 series GPS receiver at a site located $7.1 \mathrm{~km}$ upglacier from the terminus (S2, Figure 1), processed to give daily ice velocities as described by Bartholomew et al. [2011a].

\section{Results}

\subsection{Temperature and Melt}

[15] Temperature at $\mathrm{S} 1$ briefly rose above $0^{\circ} \mathrm{C}$ on several days during April (Figure 2a), causing some surface melting on the lower glacier. A series of three warm spells, interspersed with subzero temperatures, commenced on 1 May, which generated a corresponding series of spikes in melt rate. Between 21 and 26 May, temperatures at S1 reached a peak of $12.7^{\circ} \mathrm{C}$ (not surpassed at this location until 2 September), and the seasonal peak melt rate of $13.75 \mathrm{~cm} \mathrm{~d}^{-1}$ was recorded. Temperature at $\mathrm{S} 1$ remained consistently above freezing between 18 May and 7 September.

\subsection{Discharge}

[16] A small (discharge $<1 \mathrm{~m}^{3} \mathrm{~s}^{-1}$ ) proglacial stream existed upon arrival at the field site on 28 April. At this time the glacier surface was predominantly covered by a thin layer of snow, with small meltwater pools forming in some hollows. Discharge exceeded $1 \mathrm{~m}^{3} \mathrm{~s}^{-1}$ for the first time on 8 May, and rose rapidly to an initial spike of over $50 \mathrm{~m}^{3} \mathrm{~s}^{-1}$ on 11 May (Figure 2b). This was followed by a period of freezing temperatures (Figure 2a), with discharge remaining below $15 \mathrm{~m}^{3} \mathrm{~s}^{-1}$ between 16 and 22 May. Discharge then rose in a stepwise manner over a 40 day period, reaching a value of $\sim 340 \mathrm{~m}^{3} \mathrm{~s}^{-1}$ on $1 \mathrm{July}$. The end of June marked a change from a trend of rising discharge to a period of relatively consistent mean daily discharge $\left(\sim 300 \mathrm{~m}^{3} \mathrm{~s}^{-1}\right)$ with large diurnal cycles (amplitude $30-40 \mathrm{~m}^{3} \mathrm{~s}^{-1}$ ). The seasonal maximum of $\sim 400 \mathrm{~m}^{3} \mathrm{~s}^{-1}$ was reached on 30 July, and followed by a general decline until the record ended at $\sim 230 \mathrm{~m}^{3} \mathrm{~s}^{-1}$ on 27 August. Cumulative discharge over the monitoring period between 6 May and 27 August was $1.9 \times 10^{9} \mathrm{~m}^{3}$.

\subsection{Moulin Water Levels}

[17] All three monitored moulins exhibited substantial variations in water level over diurnal cycles, at times exceeding the local flotation level (Figure 2c). The relative magnitude of the spikes in water level recorded at the three moulins reflects in part the depth of the pressure transducer below the ice surface, as the lower range of the water level fluctuations are lost below the levels of the sensors.

[18] L1 showed three periods of high and variable moulin water level during May, with water backing up and pooling on the ice surface on 2, 3, 7, 8, and 9 May (Figure 3). Water level at L4 reached increasingly high levels from sensor deployment on 25 May to 1 June (Figure 2cii). Water level then appeared to drop abruptly to below the level of the sensor $(<-38 \mathrm{~m})$ on 3 June. As the sensor was not downloaded until 12 June, we cannot be certain whether this represents an actual drop in water level, or a sensor malfunction (for example, the pressure transducer becoming plugged with ice). There was one further small spike on 16 June, after which the sensor became frozen within the moulin, making it impossible to retrieve the data. L7 showed five 


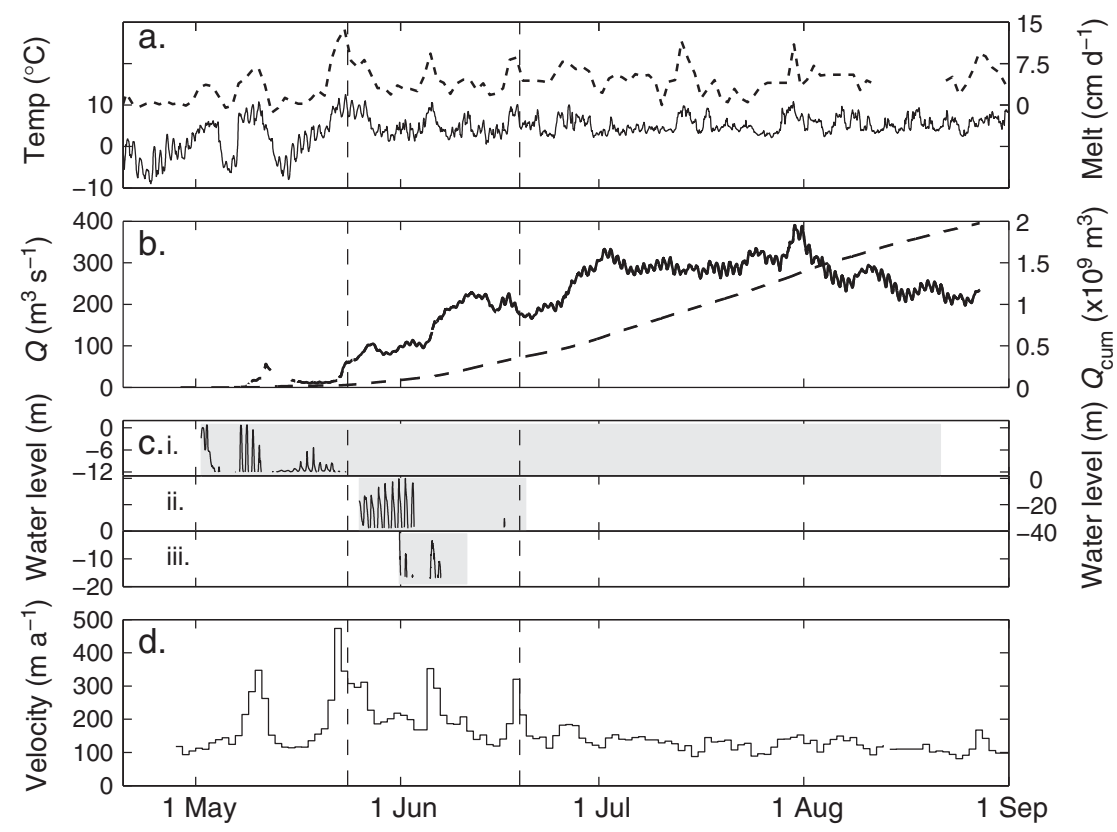

Figure 2. (a) Temperature (solid line) and surface melt rate (dashed line) recorded on Leverett Glacier at $\mathrm{S} 1,450 \mathrm{~m}$ above sea level; (b) Bulk discharge, $Q$ (solid line) and cumulative discharge $Q_{\text {cum }}$ (dashed line); (c) Level of pooled water in (i) L1, (ii) L4, and (iii) L7 (m), expressed relative to the height of the ice surface at the upglacier moulin lip (L1 and L4) or relative to an arbitrary datum (L7). Shaded area indicates duration of record. Water pressure should equal ice-overburden pressure when water level reaches approximately $-4 \mathrm{~m}$ (L1), $-19 \mathrm{~m}$ (L4), and $-32 \mathrm{~m}$ (L7) relative to the ice surface (note that L7 water level is displayed relative to an arbitrary datum and not the ice surface); d. Mean daily ice velocity at S2. Vertical dashed lines indicate approximate points of transition between (from left to right) spring, early summer, and late summer, as defined in section 6.1.

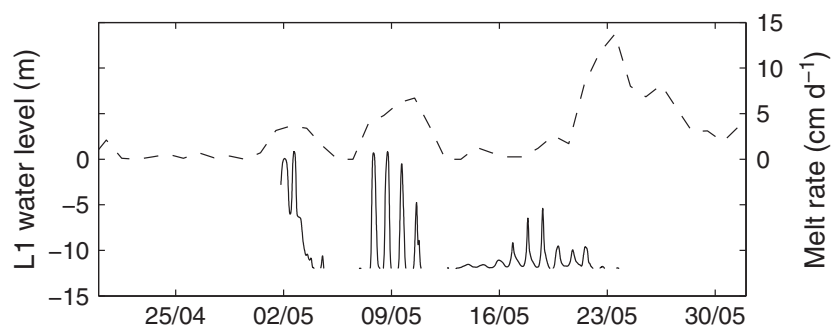

Figure 3. Detail for period of commencement of melt on lower glacier, showing L1 water level (solid line) and melt rate at $\mathrm{S} 1$ (dashed line).

spikes in water pressure between sensor deployment on 31 May and 6 June (Figure 2ciii), after which it also became irretrievably frozen.

\subsection{Flow Velocity}

[19] Flow velocity through the en/subglacial drainage system was calculated for each tracing experiment by dividing the straight line distance from the moulin to the portal by the time taken for the dye to travel through the glacier [e.g., Seaberg et al., 1988; Willis et al., 1990]. Total travel time was taken as the time between dye injection and the peak of the dye breakthrough curve; to obtain the en/subglacial travel time, it was necessary to remove the time taken for the proglacial section of the journey from the portal to the fluorometer [Hock and Hooke, 1993]. This was estimated for each experiment using a linear velocity-discharge relationship for the proglacial river $\left(\mathrm{R}^{2}=0.93\right)$, produced using velocities obtained from 25 river dye traces conducted during the 2010 melt season over a $1-1.5 \mathrm{~km}$ reach of the proglacial river upstream of the fluorometer (Figure 4).

[20] The lowest flow velocities were obtained from the earliest dye tracing experiments, with the three injections at L1 and L2 between 2 May and 16 May generating values in the range of $0.04-0.12 \mathrm{~ms}^{-1}$ (Figures 5a and 6a). There was then a general increase in flow velocity from all moulins during the rising limb of the hydrograph up to July 1, although flow velocity from L1 peaked on 27 May at $1.49 \mathrm{~ms}^{-1}$. Prior to 27 May the range of flow velocities observed from all moulins was $0.04-0.30 \mathrm{~ms}^{-1}$, whereas beyond this date all flow velocities fell in the range of $0.32-1.49 \mathrm{~ms}^{-1}$. Scarcity of tests from L14 prevents the examination of temporal trends in flow velocity from this moulin, but the available values are consistent with those from L4 and L7. There is no obvious spatial trend in flow velocity, with L2 producing the lowest values and L1, L4 and L7 all generating the highest values over a given period of the season.

\subsection{Dispersion}

[21] Dye breakthrough curves from each experiment are given in the auxiliary material, with a smaller number of examples shown in Figure 7 . With the exception of the experiments at L1 on 2 May and L2 on 16 May (Figure 7b), all curves exhibited only one peak, and most displayed a characteristically asymmetric smooth form [Fountain, 1993b; Seaberg et al., 1988; Willis et al., 1990] with the 


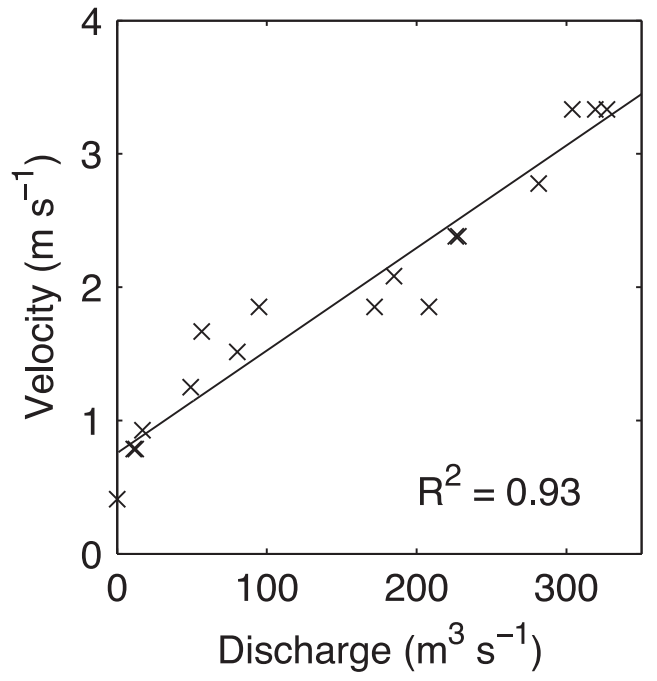

Figure 4. Relationship between discharge and velocity in the proglacial river between the portal and the fluorometer.


Figure 5. Values derived from dye tracing experiments at L1 (black circles) and L2 (grey circles). (a) Flow velocity, $u_{m}$; (b) Modeled distributed component of drainage system, $x_{d}$; (c) Dispersivity, $d$; (d) Storage retardation index, $S R$. Vertical dashed lines indicate approximate points of transition between (from left to right) spring, early summer and late summer, as defined in section 6.1.

falling limb of dye concentration showing varying degrees of elongation relative to the rising limb (Figure 7a). There was however a strong seasonal evolution of breakthrough curve form, with curves becoming more peaked and symmetrical as discharge increased (Figure 7a).


Figure 6. Values derived from dye tracing experiments at L4 (black circles), L7 (grey circles), and L14 (open circles). (a) Flow velocity, $u_{m}$; (b) Modeled distributed component of drainage system, $x_{d}$; (c) Dispersivity, $d$; (d) Storage retardation index, $S R$. Vertical dashed lines indicate approximate points of transition between (from left to right) spring, early summer and late summer, as defined in section 6.1. Note that the scales on the vertical axes differ from those used in Figure 5.

\subsection{Ice Velocity}

[22] Mean ice velocity at S2 between 1 May and 1 September was $155 \mathrm{~m} \mathrm{a}^{-1}$ (Figure 2d). Ice velocity exceeded $300 \mathrm{~m} \mathrm{a}^{-1}$ during four high-velocity events in May and June, with a maximum of $474 \mathrm{~m} \mathrm{a}^{-1}$ recorded on 22 May, but remained comparatively low and stable during July and August.

\section{Interpretation}

\subsection{Moulin Water Level}

[23] Moulin water levels became less sensitive to supraglacial melt input (as inferred from surface melt rates) as the season progressed. This is clearest at L1, where the water level record is most complete (Figure 3). During the period of surface melting between 1-5 May, the water level in the moulin rose as high as the glacier surface, demonstrating that the drainage system was unable to discharge water at the rate it entered the moulin. Melting then ceased on the 6-7 May and there was a net drainage of water out of the moulin. During the next period of melting (8-12 May), day time water level initially reached the glacier surface but then began to decline in spite of rising melt rates. There was a further short period of freezing conditions during which water level remained below the level of the sensor, then melting recommenced and the englacial water level rose once again. However, despite the high melt rates during 



Figure 7. Observed dye breakthrough curves. Date of injection given on figure. (a) Examples of smooth curves from injections at L7; (b) Irregular curves from injections at L1 and L2. (c) Irregular curve from injection at L4 on 4 June. Dye concentration has been normalized to equalize the area under the observed breakthrough curves. All breakthrough curves can be seen in the auxiliary material.

this period, the water level soon fell again and was not recorded at the level of the sensor after 22 May.

[24] From this sequence, it is apparent that the efficiency of the drainage system increased in response to increased meltwater input. The rise in efficiency was not instantaneous however, causing an imbalance between discharge into and out of the englacial system, and a corresponding increase in englacially stored water, at times when the amount of surface runoff was increasing. Similarly, the available data from L4 and L7 show that moulin water levels were high and variable during the early part of the melt season. The data are limited however by their patchiness (due to both the tendency of the water level to drop below the level of the sensor and the freezing in place of the sensors) and the method's inability to inform us as to the structure of the underlying subglacial drainage system. A more detailed and complete picture of drainage system structure and evolution can be obtained by examining the results of the dye tracing experiments.

\subsection{Flow Velocity}

[25] Flow velocity increased at all moulins (Figures 5a and 6a) as discharge rose through May and June (Figure 2b). Traditionally, increases in drainage system efficiency on a seasonal timescale have been viewed in terms of a transition from a predominantly distributed to predominantly channelized drainage system [e.g., Fountain and Walder, 1998; Hubbard and Nienow, 1997]. The transition between these systems, and the subsequent impact on subglacial water pressures, has formed the core of the debate surrounding the relationship between runoff and ice velocity in the ablation zone of the Greenland Ice Sheet [Bartholomew et al., 2011a; Sundal et al., 2011]. Because flow in channelized systems is expected to occur at velocities 1-2 orders of magnitude greater than in distributed systems [Nienow et al., 1998], analysis of the dye flow velocities allows us to examine whether a transition between these two systems is observed within the dye tracing data from Leverett Glacier. In doing so, we seek to differentiate between variation in flow velocity caused by a transition between two distinct drainage morphologies and that which results from temporal variation in the morphology and drainage conditions of fully channelized pathways [Nienow et al., 1996].

[26] Flow velocity represents an average of conditions between the moulin and portal, which may comprise sections of distributed and channelized drainage pathway [Fountain, 1993b; Nienow et al., 1998]. If characteristic velocities are presented for channelized and distributed flow, then it is possible to calculate the relative proportions of these two systems required to produce the observed values of mean flow velocity. This is given from

$$
x_{d}=\frac{\left\{x u_{d}\left[\left(x / u_{m}\right) u_{c} u_{d}\right]\right\}}{\left(u_{d}-u_{c}\right)}
$$

[27] [Willis et al., 1990, equation (22)] where $x$ is the straight line distance from the moulin to the portal, $x_{d}$ is the length of the distributed component of the flow path, $u_{c}$ is the mean flow velocity in channelized systems, $u_{d}$ is the mean flow velocity in distributed systems, and $u_{m}$ is the overall mean flow velocity. Following Nienow et al. [1998], $u_{d}$ was estimated at $0.025 \mathrm{~ms}^{-1}$, based on the results of tracer studies at the Haut Glacier d'Arolla [Nienow et al., 1998], Midtdalsbreen [Willis et al., 1990] and Variegated Glacier [Kamb, 1987]. $u_{c}$ is likely to vary through the season as channel cross section, roughness and pressure fluctuates [Gulley et al., 2012; Nienow et al., 1996; Werder et al., 2010]. To examine the impact of this on the outcome of equation (1), $x_{d}$ was calculated twice for each tracing experiment. Firstly, $u_{c}$ was kept constant at a typical proglacial channel velocity of $2 \mathrm{~ms}^{-1}$ (Figure 4). For the second calculation, $u_{c}$ was assumed on each occasion to be equal to the velocity of the proglacial river at its concurrent discharge (calculated from the velocity-discharge relationship described in section 4.4 and Figure 4), in order to simulate a seasonal increase in subglacial channel velocity as discharge increased. The results proved to be insensitive to 
the selection of $u_{c}$, with the two calculations producing values of $x_{d}$ that varied by less that $2 \%$ for each dye tracing experiment (see auxiliary material). As such, only the results produced using a constant $u_{c}$ are shown in Figures $5 \mathrm{~b}$ and $6 \mathrm{~b}$.

[28] While equation (1) is insensitive to the choice of $u_{c}$, substantial uncertainty remains in the calculation of $x_{d}$, in particular due to the likely underestimation of $x$ (which does not account for the sinuosity of the flow path) and because $u_{d}$ is only an approximate velocity for flow through distributed systems [Nienow et al., 1998]. As such, the absolute values of $x_{d}$ shown in Figures $5 \mathrm{~b}$ and $6 \mathrm{~b}$ should be treated cautiously. The only indication of drainage at velocities representative of a distributed drainage system comes from the very earliest tracing experiments, which were undertaken at L1 (2 May) and L2 (8 and 16 May) (Figure 5b). It is possible therefore that these experiments were undertaken prior to the formation of channels linking these moulins with the portal, with drainage partly occurring through a system closed up due to ice deformation over winter.

[29] $x_{\mathrm{d}}$ remained small and relatively constant at all sites from late May onward, with the initial drop from $\sim 6$ to $2 \%$ at L4 insignificant relative to the decline in $x_{\mathrm{d}}$ following the first experiments at L1 and L2 (Figures 5b and 6b). Given the uncertainties, these values are not significantly different from zero. This suggests that channelization of the drainage system along this lower $14 \mathrm{~km}$ of the glacier was complete within at most 4 weeks of the onset of melting. At this time, discharge was $\sim 100 \mathrm{~m}^{3} \mathrm{~s}^{-1}$, a quarter of its peak value in late July, while cumulative discharge was at only $\sim 5 \%$ of the total seasonal flux. It is likely that variation in velocity beyond this point reflects a combination of factors which influence the rate of flow through channelized drainage systems, including channel roughness, pressure and supraglacial input at the time of dye injection [Nienow et al., 1996; Schuler et al., 2004; Schuler and Fischer, 2009; Werder et al., 2010], rather than a transition between distributed and channelized drainage morphologies.

\subsection{Dispersion}

[30] As discharge and flow velocity increased through May and June, the dispersion of the dye cloud between injection and detection decreased, resulting in more peaked dye breakthrough curves (Figure 7a). This is interpreted as a function of increasing system efficiency - as the dye is rapidly transported through a relatively simple channel network, there is less time for the cloud to be dispersed, and fewer obstacles to cause this dispersion [Seaberg et al., 1988]. More information on drainage system structure and conditions can be obtained from a more detailed analysis of the form of the dye breakthrough curves.

\subsubsection{Irregular Breakthrough Curves}

[31] If dye passes along a drainage system in which flow paths diverge and reconverge, then multiple peaks or irregularities may be found in the dye breakthrough curve. Of the 43 dye tracing experiments undertaken, only the first experiment from L1 (2 May) and second experiment from L2 (16 May) produced multiple peaks. On both occasions there is a clear initial peak, followed by a period of lower, fluctuating dye concentration (Figure 7b). Additionally, the breakthrough curve from L4 on 4 June has only one peak, but exhibits an obvious shoulder on the rising limb of dye concentration (Figure 7c). The form of these curves suggests that at this time there was a preferred, more rapid drainage pathway, but that some dye was diverted down anabranching slower routes [Seaberg et al., 1988], indicating structural inefficiencies existed in the early season drainage system that disappeared as discharge rose.

\subsubsection{Dispersivity}

[32] Dispersion of the dye cloud is promoted by a range of morphological factors, including high degrees of braiding, sinuosity and roughness [Gulley et al., 2012; Seaberg et al., 1988]. Very high dispersion rates have therefore been interpreted as indicative of flow through a distributed system [Bingham et al., 2005; Nienow et al., 1998], but these morphological factors remain relevant controls on dispersion in a channelized system [Gulley et al., 2012; Hock and Hooke, 1993; Seaberg et al., 1988]. Dispersion also occurs in the englacial drainage system, with englacially stored water increasing the dispersion of the dye cloud [Fountain, 1993b; Schuler et al., 2004]. Higher rates of dispersion are therefore associated with less efficient drainage morphologies and conditions. It is not easy however to distinguish between these processes, with the dispersion at any time reflecting a combination of factors [Schuler et al., 2004].

[33] In glacial systems, dispersion is often examined in the form of dispersivity $\left(d=D / u_{m}\right)$, which describes the relationship between the rate at which dye is dispersed $(D)$ and the rate at which it is advected through the glacier $\left(u_{\mathrm{m}}\right)$, with higher dispersivities indicative of lower drainage efficiency [Fischer, 1968; Seaberg et al., 1988]. D is the dispersion coefficient, which describes the rate at which the dye cloud is dispersed. The dispersion coefficient can be calculated by fitting a onedimensional advection-dispersion model to a dye breakthrough curve [Schuler et al., 2004; Willis et al., 2009]

$$
c(t)=\frac{u_{m}}{Q} \frac{V}{(4 \pi D t)^{1 / 2}} \exp \left[-\frac{\left(x-u_{m} t\right)^{2}}{4 D t}\right]
$$

where $c$ is the concentration of dye passing a fixed point downstream of the injection site at time $t, V$ is the volume of injected dye, $x$ is the distance in the along flow direction, $Q$ is discharge and other symbols are as defined above [Behrens et al., 1975; Brugman, 1986; Schuler et al., 2004; Seaberg et al., 1988; Willis et al., 1990]. This model does not account for the process of storage retardation, whereby dye is temporarily stored then rereleased back into the main flow [Schuler et al., 2004; Willis et al., 1990, 2009]. This process causes the breakthrough curve, and particularly the falling limb of dye concentration, to become more elongated. As such, only the rising limb was considered when optimising the fit between the observed and modeled breakthrough curves [Schuler et al., 2004; Willis et al., 2009], adjusting $u$ and $V$ such that the magnitude and timing of the modeled curve was in agreement with observations, and adjusting $D$ to minimise error between the two rising limbs (Figure 8 and auxiliary material).

[34] Dispersivity is plotted for all experiments in Figures 5c and $6 \mathrm{c}$, with the exception of the experiment at L4 on 4 June, where the irregular form of the rising limb makes this method of calculation inappropriate (Figure 7c). The low and stable values of dispersivity displayed for experiments from all moulins during July and August indicate that there was little change in the form of the drainage system during this period. 
COWTON ET AL.: GREENLANDIC DRAINAGE EVOLUTION
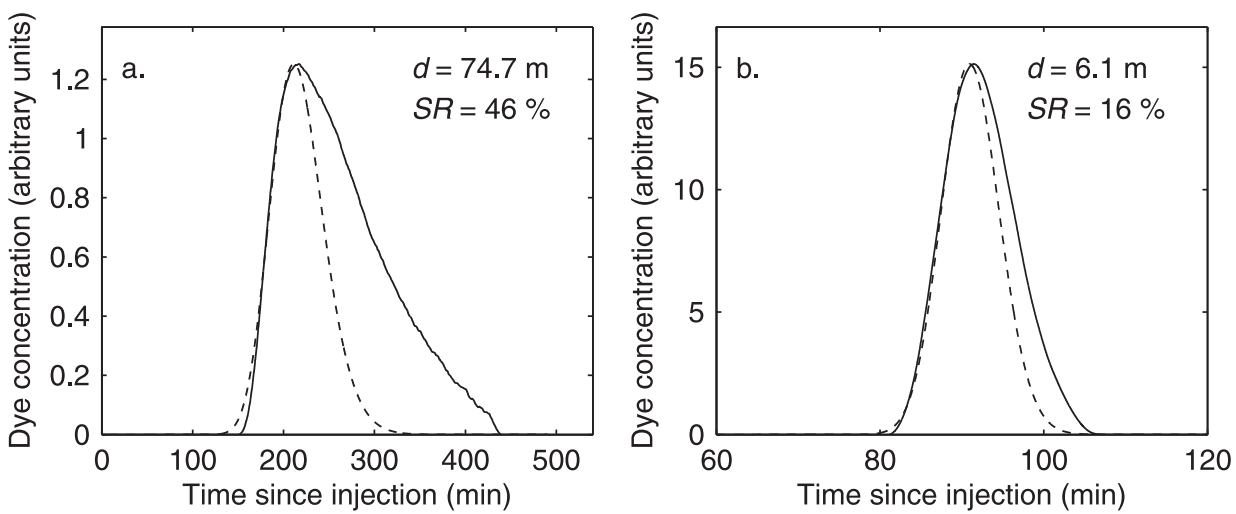

Figure 8. Examples of observed (solid lines) and modeled (dashed lines) dye breakthrough curves. (a) L7 31 May. (b) L7 4 July. Dye concentration has been normalized to equalize the area under the observed breakthrough curves. All breakthrough curves can be seen in the auxiliary material.

During May and June however the records from each moulin show a trend of declining dispersivity, most notably at L4 and L7. This demonstrates that some process was occurring during these early experiments to cause the dye cloud to be dispersed more rapidly than would be expected in an efficient channel at the observed flow velocities. The effects of this process appear to decline as the season progresses, stabilising at the lower four moulins by the end of June.

\subsubsection{Storage Retardation}

[35] Because the model is fitted only to the rising limb of the breakthrough curve, there is often a poor agreement between the falling limbs of the observed and modeled curves (Figure 8), which is attributed primarily to the process of storage retardation [Schuler et al., 2004; Willis et al., 1990]. As such, the agreement between the entirety of the observed and modeled breakthrough curves can be used as an indication of the importance of storage retardation as a dispersive process [Brugman, 1986; Willis et al., 2009]. The percentage of the area under each observed curve that was not explained by the equivalent modeled curve was therefore taken as a storage retardation index, $S R$, with greater values indicating a greater importance of storage retardation.

[36] $S R$ is shown in Figures 5d and 6d. For experiments where the detected dye concentration was low and the duration of the dye breakthrough curve brief, the form of the curve was distorted by noise in the fluorometer signal, leading to large uncertainties in storage retardation. This is particularly problematic for the results from L1 and L2, where minimal volumes of dye were used to limit costs, and probably explains the scatter of values shown in Figure 5d. A clearer trend is visible at the upper three moulins (Figure 6d), with storage retardation declining during the first half of June before remaining comparatively low and stable during July and August.

\subsubsection{Significance for Drainage System}

[37] The highest values of $S R(>60 \%)$ are associated with the complex breakthrough curves obtained during the early experiments undertaken at L1 and L2 (Figures 5d and 7b), where flow divergence increases the difference between the observed and modeled curves. With the exception of these, and particularly at the upper three moulins where the scatter in $S R$ is reduced, there is good agreement between the seasonal trends in dispersivity and storage retardation (Figures $5 \mathrm{c}-5 \mathrm{~d}$ and Figures 6c-6d). Both parameters showed a general decline over time until stabilising during late June and July, and both were particularly high for the initial experiments at L4, L7 and L14 during late May and early June. This indicates that some process was acting early in the season to disperse the dye more rapidly than would be expected by flow along an efficient channel network.

[38] Three principal explanations can be offered for this. The first is that this trend represents the gradual expansion of the subglacial channel network at the expense of the distributed drainage system [Nienow et al., 1998]. This seems unlikely however, as the high flow velocities observed from L4, L7 and L14 at the time of highest dispersivity and storage retardation during late May and early June indicate that the drainage system was already fully channelized by this time (Figure 6).

[39] The second possibility is that this reflects an increase in efficiency in the subglacial channel system. Small channels are hydraulically rough compared to larger channels, and may be characterised by small-scale braiding and sinuosity as water is diverted around obstacles in the bed [Gulley et al., 2012; Hock and Hooke, 1993; Seaberg et al., 1988]. A1though the bulk discharge of $\sim 100 \mathrm{~m}^{3} \mathrm{~s}^{-1}$ during late May demonstrates that the principal subglacial channels were well developed by this point, tributary channels may have been sufficiently small for the bed to have exerted a large influence on flow. The sustained discharge of surface meltwaters through these channels as surface melt continued would cause the channel cross sections to expand [Röthlisberger and Lang, 1987], increasing drainage efficiency and so causing dispersivity and storage retardation to decrease. Similarly, increasing flow depth due to rising discharge in an open channel would cause hydraulic roughness, and as such dispersivity and storage retardation, to decrease [Gulley et al., 2012]. Open channel flow does not however seem likely to be the dominant drainage process beneath the glacier, as high and variable englacial water levels demonstrate pressurization of the drainage system early in the melt season (Figure 2c), and the reverse bed slope requires subglacial drainage to be pressurised from beyond $\sim 3 \mathrm{~km}$ upglacier (Figure 1b). Although dispersion in the proglacial channel is likely to have declined as discharge rose, the highest dispersivities at the upper three moulins were recorded when dispersivity at the lower two moulins was low, demonstrating that the cause of the enhanced dispersion was located upglacier and not in the proglacial environment. As 
such, if increasing channel efficiency is an important cause of decreasing dispersivity and storage retardation, this is expected to occur primarily due to expansion of the cross-sectional area of pressurised channels, and not due to increasing discharge in open channels.

[40] The third possible explanation for the decline in dispersivity and storage retardation is that this trend reflects changes in the englacial system. At South Cascade Glacier, Washington State, Fountain [1993b] was unable to account for the shape of dye breakthrough curves without incorporating a storage term, which he inferred to be pooling in the englacial drainage system. Our observations support the association of high dispersivity and storage retardation with periods of transient englacial storage. In particular, at the time of high dispersivity and storage retardation during the early experiments at the three upper moulins, the englacial water level reached almost to the glacier surface (Figure 2c), and dye was observed to spread out through the pooled water. The subsequent release of dye at increasingly dilute concentrations from such a pool would produce a smooth but elongated dye breakthrough curve [Fountain, 1993b], much like those observed at this time (Figure 7a, auxiliary material).

[41] In reality, it is likely that both channel efficiency and englacial storage contributed to the seasonal patterns of dispersivity and storage retardation. The greatest volumes of englacial storage were observed at the time of the early experiments, with the level of water pooled in moulins reaching close to the ice surface, and it is likely that this exerted a strong influence on the dispersal of dye [Fountain, 1993b]. These high water levels were generated by water entering the drainage system more rapidly than it could be discharged, which is most likely to occur at a time of increasing runoff into channels which are relatively small and inefficient and so easily overwhelmed. The high values of dispersivity and storage retardation may therefore reflect a combination of high storage and low channel efficiency, with dispersivity and storage retardation then falling as channel cross sections expanded in response to sustained melt input, allowing englacial storage to drop.

\section{Discussion}

\subsection{Seasonal Evolution of Drainage System Morphology}

\subsubsection{Spring}

[42] The extremely high englacial water levels recorded at L1 following the onset of monitoring on 1 May demonstrate that the drainage system was unable to discharge surface melt water at the rate at which it was entering the moulin (Figure 2c). At this time, the very low flow velocities indicate that part of the drainage pathway from L1 and L2 was through an inefficient, distributed system (Figures 5a-b). This is supported by signs of flow divergence in the shape of dye breakthrough curves from L1 and L2, suggesting the existence of multiple flow paths (Figure 7b). It seems likely that at this stage we are observing the initial input of surface meltwater into an inefficient drainage system which has largely closed through ice deformation over the winter, leaving it with insufficient capacity to discharge the rapidly rising inputs of surface meltwater [Fountain, 1993b; Röthlisberger and Lang, 1987].
[43] Over the next $\sim 20$ days the englacial water level at L1 dropped, in spite of increasing melt rates, indicating a rise in the output discharge from the englacial system due to increasing drainage efficiency (Figure 3). Rising flow velocities from L1 and L2 (Figures 5a-5b) and the end of flow divergence indicate that this was most likely due to a growth in the extent and efficiency of the channel network. During this initial phase therefore, observed at L1 and L2 during the first half of May, the principal cause of increasing drainage system efficiency is interpreted to be the growth of a channelized drainage network at the expense of the winter distributed drainage system. This is in keeping with the processes of seasonal drainage system evolution inferred for alpine and High Arctic glaciers [Bingham et al., 2005; Fountain and Walder, 1998; Nienow et al., 1998; Willis et al., 1990].

\subsubsection{Early Summer}

[44] The relatively high flow velocities (Figures 6a-6b) and absence of visible flow divergence recorded during the first dye tracing experiments at the three upper moulins (undertaken 29 May to 2 June) indicate that by this point the subglacial drainage channels had expanded to connect the portal with moulins as far as $14 \mathrm{~km}$ upglacier. Moulin water level records from L4 and L7 demonstrate that in spite of these channels however, meltwater inputs were still capable of exceeding drainage capacity, leading to englacial water storage (Figure 2c). Throughout June, there was a continued rise in flow velocity from these moulins, indicating an increase in the efficiency of and discharge through the subglacial channels (Figure 6a). In accordance with this, the changing form of the dye breakthrough curves suggests a decline in the volume of water storage in the englacial system over this same period, reaching a low and relatively stable level by early July (Figures 6c-6d). This is important, because it implies that rising meltwater inputs regularly caused water to back up into the englacial drainage system for a period of at least 2-4weeks following the formation of channels linking these moulins to the portal. It is likely that this period of imbalance reflects the continual readjustment of channel cross section to rising melt inputs as the season progressed and bulk discharge rose from $\sim 100$ to $300 \mathrm{~m}^{3} \mathrm{~s}^{-1}$ (Figure 2b) [Bartholomew et al., 2011a]. As such, the increase in subglacial channel cross section may form a second phase of drainage system evolution influencing the relationship between meltwater inputs and subglacial water pressure long after the channelized drainage network has formed [Bartholomew et al., 2011a, 2012].

\subsubsection{Late-Summer}

[45] By early July, the rise in bulk discharge has slowed (Figure 2a) and the drainage system has reached a relatively stable configuration across a distance extending at least as far as L7 (6.6 km from the portal). From this time on, the observed dispersion of injected dye can be well explained by flow along a stable system of efficient channels, with morphological changes and englacial storage inferred to be much less important than during May and June (Figures 5c-5d and Figures 6c-6d).

\subsection{Implications for Ice Dynamics}

[46] Subglacial hydrology and ice dynamics are closely linked, with ice velocities, driven by basal sliding, increasing with water storage and basal water pressure [Bartholomaus 
et al., 2008; Iken, 1981; Iken and Bindschadler, 1986; Kamb, 1987; Röthlisberger and Lang, 1987; Schoof, 2010]. These conditions occur when surface meltwater inputs exceed the existing capacity of the drainage system [Bartholomaus et al., 2008; Röthlisberger and Lang, 1987]. There should therefore be a correspondence between the inferred seasonal drainage evolution and ice dynamics on Leverett Glacier, and in particular periods of low drainage efficiency, high water storage and elevated ice velocity.

[47] Ice velocity records from S2 show seasonal variations in ice dynamics that reflect the inferred processes of drainage evolution (Figure 2d). Major spikes in ice velocity, centred on 11 and 22 May, occurred during the period of "spring" drainage configuration, when drainage system efficiency was low but discharge was increasing rapidly (Figure 2) (analogous to the "spring events" often reported at glaciers [Mair et al., 2003; Röthlisberger and Lang, 1987]), causing the level of englacially stored water to rise as high as the glacier surface (Figure 2c). Following this, ice velocity then remained relatively high, albeit falling, during June, with short-term acceleration events corresponding to rapid rises in discharge [Bartholomew et al., 2011a]. This corresponds to the second phase of drainage evolution during the "early summer', in which the drainage system is inferred to be channelized but these channels were regularly overwhelmed by rising meltwater inputs, leading to transient water storage. It was not until the "late summer" period, when larger and more efficient channels, less sensitive to rising melt input, had formed, and discharge began to stabilise and then decline, that ice velocity at S2 became relatively low and stable [Bartholomew et al., 2011a].

[48] The correspondence between ice dynamics and drainage evolution is highlighted in Figure 9. This demonstrates a correlation between ice velocity at S2 and dispersivity for dye tracing experiments at L4, L7 and L14. It is unlikely that the traced drainage pathways exert an individual influence on the recorded ice velocity-instead, the correlation probably indicates that these flow paths were representative of the wider drainage system at the time of the experiments. Although all these data come from a period in which the drainage system along this section of the glacier is thought to be channelized, they indicate that higher ice velocities occurred when the channels were hydraulically less efficient and englacial storage was high. This demonstrates that seasonal evolution of the drainage system remains important after subglacial channels have formed, and supports the

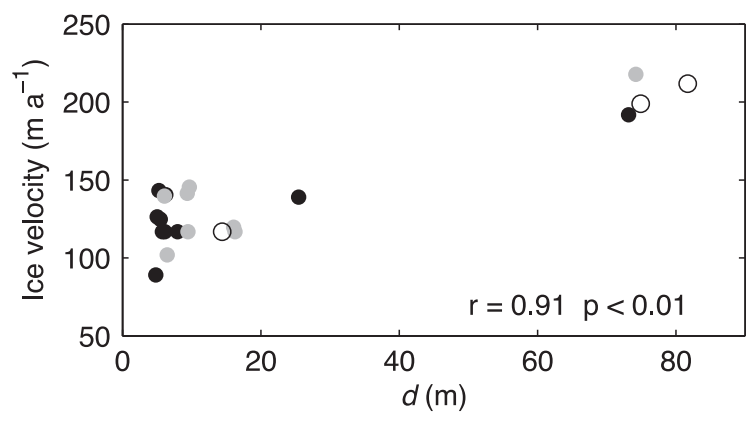

Figure 9. Comparison of ice velocity at S2 with dispersivity. Symbols indicate whether the dye was injected into L4 (black circles), L7 (grey circles), or L14 (open circles). assertion that variations in meltwater input can generate large fluctuations in ice velocity even where a fully channelized drainage system exists [Bartholomaus et al., 2008; Bartholomew et al., 2011a, 2012; Schoof, 2010].

\subsection{Applicability to the Ablation Zone of the Greenland Ice Sheet}

[49] The results of our dye tracing study suggest that there are many similarities, except in scale, between the seasonal evolution of the drainage system of this section of Leverett Glacier and that observed at smaller temperate and polythermal glaciers [e.g., Behrens et al., 1975; Bingham et al., 2005; Collins, 1982; Fountain, 1993b; Hock and Hooke, 1993; Nienow et al., 1998; Seaberg et al., 1988; Willis et al., 1990]. For logistical reasons, our study was limited to the lowermost $14 \mathrm{~km}$ of glacier, but subglacial drainage of surface meltwaters is expected to occur beneath at least $60 \mathrm{~km}$ of Leverett Glacier [Bartholomew et al., 2011b; Cowton et al., 2012], and for greater than $80 \mathrm{~km}$ in neighbouring catchments [Bartholomew et al., 2011a]. Perhaps the greatest difference between the upper reaches of the catchment and the area described in this study is the extremely thick, cold ice separating the surface and bed of the glacier, with ice thickness exceeding $1 \mathrm{~km}$ at $50 \mathrm{~km}$ inland from the margin of Leverett Glacier [Allen, 2010]. The hydrological impacts of this are likely twofold.

[50] Firstly, the thick ice will generate very high deformation rates at the bed, causing rapid closure of low-pressure zones [Cuffey and Paterson, 2010]. Nonetheless, ice velocities show similar seasonal patterns in regions of $\sim 1000 \mathrm{~m}$ thick ice to those observed near the margin, with the sensitivity of ice velocity to melt water inputs decreasing as the summer progresses [Bartholomew et al., 2010, 2011a; Hoffman et al., 2011]. This suggests subglacial channel growth is sufficient to offset the rapid deformation, allowing efficient drainage channels to evolve as observed on the lower glacier [Bartholomew et al., 2010, 2011a; Hoffman et al., 2011]. Secondly, the thick, cold ice makes it more difficult to establish a hydrological connection between the surface and the bed. Catastrophic lake drainage through hydrofracturing is therefore a key mechanism of moulin formation [Das et al., 2008; van der Veen, 2007]. This means that the input of surface meltwater to the glacier bed is often delayed until a lake drainage event has occurred [Bartholomew et al., 2011a]. Because the initial discharge of meltwater during a lake drainage event is extremely large, it is likely to force the drainage system to evolve rapidly to an efficient state [Das et al., 2008; Pimentel and Flowers, 2011]. As such, a prolonged period of drainage system evolution in response to gradually increasing melt inputs, as seen on the lower glacier, may be less likely in the upper parts of the catchment.

[51] The hydrology of the Greenland Ice Sheet may depend not only on distance from the ice margin, but also on the type of ice margin. Ice velocities near the terminus of marine-terminating outlet glaciers are often an order of magnitude greater than at land-terminating glaciers [Rignot and Kanagaratnam, 2006]. Kamb et al. [1985] argued that rapid basal sliding during glacial surges inhibited the growth of efficient subglacial channels, maintaining high-pressure drainage through linked-cavities, which in turn helped sustain the high sliding velocities. It is difficult however 
to conceptualise how the vast quantities of melt water formed in these Greenland catchments each summer could be discharged through a distributed drainage system, and the emergence of turbid meltwater plumes from marineterminating glaciers points to the existence of efficient subglacial channels [Lewis and Smith, 2009; Sole et al., 2011]. Furthermore, observations of ice motion at numerous marine-terminating glaciers in west Greenland reveal seasonal flow patterns comparable with those on land-terminating glaciers, suggesting a similar process of drainage system evolution [Howat et al., 2010; Sole et al., 2011]. These observations, suggesting the seasonal evolution of drainage efficiency beneath fast flowing ice, are difficult to reconcile with Kamb's theory of rapid ice motion sustained by inefficient distributed drainage. As such, the hydrology of tidewater glaciers requires further research.

\section{Conclusions}

[52] The results from 43 dye tracing experiments, in conjunction with moulin water level and ice velocity data, provide a detailed picture of the morphology and evolution of the drainage system of the lower $14 \mathrm{~km}$ of Leverett Glacier, west Greenland. Following the onset of seasonal melt in May, the discharge of supraglacial meltwater into moulins frequently exceeded output from the englacial system, causing the englacial water level to rise to the glacier surface during times of peak melting and ice velocity to reach its seasonal maximum. The flow velocity and dispersion of injected dye suggests a rapid transition from a distributed to channelized drainage system occurred at this time, with channels extending greater than $13 \mathrm{~km}$ upglacier by the time that discharge reached a quarter of its seasonal peak and cumulative discharge was only $5 \%$ of the observed seasonal flux. This rise in drainage efficiency is apparent in the moulin water level records, with greater meltwater inputs required to force a rise in englacial storage relative to the onset of the melt season.

[53] Dye breakthrough curves indicate drainage efficiency remained relatively low and storage high following the formation of these channels. This period was characterised by regular increases in runoff, causing meltwater to back up into the englacial system, as observed in the moulin water level records. Ice velocity remained high and variable during this period, suggesting that, when meltwater inputs are rising faster than the drainage system can adjust, hydrological forcing of ice velocity occurs despite the existence of channels [Bartholomaus et al., 2008; Bartholomew et al., 2011a; Schoof, 2010]. As the season progressed, the sustained input of meltwater allowed channel cross section to increase and storage to decline. Drainage efficiency was at its greatest, and storage lowest, during the late summer period when subglacial channels were well developed and runoff was relatively stable or declining. Correspondingly, the lowest and most stable ice velocities were recorded at this time.

\section{Notation}

$c$ dye concentration at a fixed point downstream of the injection site, p.p.m.

$d$ dispersivity, $\mathrm{m}$.

$D$ dispersion coefficient, $\mathrm{m}^{2} \mathrm{~s}^{-1}$.

$Q$ bulk discharge, $\mathrm{m}^{3} \mathrm{~s}^{-1}$.
$Q_{\text {cum }}$ cumulative bulk discharge, $\mathrm{m}^{3}$.

$S R$ storage-retardation index, $\%$

$t$ time, s.

$V$ volume of injected dye, $\mathrm{ml}$.

$x$ length of flowpath, $\mathrm{m}$.

$x_{\mathrm{c}}$ channelized proportion of flow path, $\%$.

$x_{\mathrm{d}}$ distributed proportion of flow path, $\%$.

$u_{\mathrm{c}}$ approximate mean flow velocity in channelized system, $\mathrm{ms}^{-1}$.

$u_{\mathrm{d}}$ approximate mean flow velocity in distributed system, $\mathrm{ms}^{-1}$.

$u_{\mathrm{m}} \quad$ flow velocity between moulin and portal, $\mathrm{ms}^{-1}$.

[54] Acknowledgements. This work was funded by the UK Natural Environment Research Council (through grants to Nienow, Mair, and Wadham, and a studentship to Bartholomew), the Edinburgh University Moss Centenary Scholarship (Cowton and Bartholomew), and a Carnegie Research Grant (Nienow). We thank Ian Willis, Tim Bartholomaus and an anonymous referee for valuable comments which significantly improved the manuscript.

\section{References}

Allen, C. (2010), IceBridge MCoRDS L2 Ice Thickness, Digital media. http:// nsidc.org/data/irmcr2.html, Natl. Snow Ice Data Cent., Boulder, Colo.

Alley, R. B., K. M. Cuffey, E. B. Evenson, J. C. Strasser, D. E. Lawson, and G. J. Larson (1997), How glaciers entrain and transport basal sediment: Physical constraints, Quat. Sci. Rev., 16(9), 1017-1038.

Bartholomaus, T. C., R. S. Anderson, and S. P. Anderson (2008), Response of glacier basal motion to transient water storage, Nat. Geosci., 1(1), 33-37.

Bartholomew, I., P. Nienow, D. Mair, A. Hubbard, M. A. King, and A. Sole (2010), Seasonal evolution of subglacial drainage and acceleration in a Greenland outlet glacier, Nat. Geosci., 3(6), 408-411.

Bartholomew, I., P. Nienow, A. Sole, D. Mair, T. Cowton, and M. King (2011a), Seasonal variation in Greenland Ice Sheet motion: Inland extent and behaviour at higher elevations, Earth Planet. Sci. Lett., 307, 271-278.

Bartholomew, I., P. Nienow, A. Sole, D. Mair, T. Cowton, S. Palmer, and J. Wadham (2011b), Supraglacial forcing of subglacial drainage in the ablation zone of the Greenland ice sheet, Geophys. Res. Lett., 38, L08502, doi:10.1029/2011GL047063.

Bartholomew, I., P. Nienow, A. Sole, D. Mair, T. Cowton, and M. King (2012), Short-term variability in Greenland Ice Sheet motion forced by time-varying meltwater drainage: Implications for the relationship between subglacial drainage system behavior and ice velocity, J. Geophys. Res., 117, F03002, doi:10.1029/2011JF002220.

Behrens, H., H. Bergmann, H. Moser, W. Ambach, and O. Jochum (1975), On the water channels of the internal drainage system of the Hintereisferner, Ötzal Alps, J. Glaciol., 14(72), 375-382.

Bhatia, M. P., S. B. Das, E. B. Kujawinski, P. Henderson, A. Burke, and M. A. Charette (2011), Seasonal evolution of water contributions to discharge from a Greenland outlet glacier: insight from a new isotope-mixing model, J. Glaciol., 57(205), 929-941.

Bingham, R. G., P. W. Nienow, M. J. Sharp, and S. Boon (2005), Subglacial drainage processes at a High Arctic polythermal valley glacier, $J$. Glaciol., 51(172), 15-24.

Brugman, M. M. (1986), Water flow at the base of a surging glacier, $\mathrm{PhD}$ dissertation, Calif. Inst. of Technol., Pasadena, Calif.

Collins, D. N. (1979), Sediment concentration in melt waters as an indicator of erosion processes beneath an alpine glacier, J. Glaciol., 23(89), 247-257.

Collins, D. N. (1982), Flow-routing of meltwater in an alpine glacier as indicated by dye tracer tests, Beiträge Geol. Schweiz-Hydrol., 28, 523-534.

Cowton, T., P. Nienow, I. Bartholomew, A. Sole, and D. Mair (2012), Rapid erosion beneath the Greenland ice sheet, Geology, 40(4), 343-346.

Cuffey, K. M., and W. S. B. Paterson (2010), The Physics of Glaciers, Elsevier, New York.

Das, S. B., I. Joughin, M. D. Behn, I. M. Howat, M. A. King, D. Lizarralde, and M. P. Bhatia (2008), Fracture propagation to the base of the Greenland Ice Sheet during supraglacial lake drainage, Science, 320(5877), 778-781.

Fischer, H. B. (1968), Methods for predicting dispersion coefficients is natural streams, with applications for the lower reaches of the Green and Dumwmish Rivers, Washington, U.S. Geol. Surv. Prof. Pap., 582-A.

Fountain, A. G. (1993a), Borehole water level variations and implications for the subglacial hydraulics of South Cascade Glacier, Washington State, USA, J. Glaciol., 40(135), 293-304. 


\section{COWTON ET AL.: GREENLANDIC DRAINAGE EVOLUTION}

Fountain, A. G. (1993b), Geometry and flow conditions of subglacial water at South Cascade Glacier, Washington State, USA-An analysis of tracer injections, J. Glaciol., 39(131), 143-156.

Fountain, A. G., and J. S. Walder (1998), Water flow through temperate glaciers, Rev. Geophys., 36(3), 299-328.

Gulley, J., P. Walthard, J. Martin, A. F. Banwell, D. Benn, and G. A. Catania. (2012), Conduit roughness and dye-trace breakthrough curves: why slow velocity and high dispersivity may not reflect flow in distributed systems, J. Glaciol., 58(2011), 915-925.

Hock, R., and R. L. Hooke (1993), Evolution of the internal drainage system in the lower part of the ablation area of Storglaciaren, Sweden, Geol. Soc. Am. Bull., 105(4), 537-546.

Hock, R., A. Iken, and A. Wangler (1999), Tracer experiments and borehole observations in the over-deepening of Aletschgletscher, Switzerland, in Annals of Glaciology, edited by J. Kleman, pp. 253-260, Int. Glaciol. Soc., Cambridge, U. K.

Hoffman, M. J., G. A. Catania, T. A. Neumann, L. C. Andrews, and J. A. Rumrill (2011), Links between acceleration, melting, and supraglacial lake drainage of the western Greenland Ice Sheet, J. Geophys. Res., 116, F04035, doi:10.1029/2010JF001934.

Howat, I. M., J. E. Box, Y. Ahn, A. Herrington, and E. M. McFadden (2010), Seasonal variability in the dynamics of marine-terminating outlet glaciers in Greenland, J. Glaciol., 56(198), 601-613.

Hubbard, B., and P. Nienow (1997), Alpine subglacial hydrology, Quat. Sci. Rev., 16(9), 939-955.

Hubbard, B. P., M. J. Sharp, I. C. Willis, M. K. Nielsen, and C. C. Smart (1995), Borehole water-level variation and the structure of the subglacial hydrological system of Haut Glacier d'Arolla, Valais, Switzerland, J. Glaciol., 41(139), 572-583.

Iken, A. (1981), The effect of subglacial water pressure on the sliding velocity of a glacier in an idealised numerical model, J. Glaciol., 32(97), 110-421.

Iken, A., and R. A. Bindschadler (1986), Combined measurements of subglacial water-pressure and surface velocity of Findelengletscher, SwitzerlandConclusions about drainage system and sliding mechanism, J. Glaciol., 32 (110), 101-119.

Iken, A., K. Echelmeyer, W. Harrison, and M. Funk (1993), Mechanisms of fast flow in Jakobshavns-Isbrae, West Greenland .1. Measurements of temperature and water-level in deep boreholes, J. Glaciol., 39(131), 15-25.

Kamb, B. (1987), Glacier surge mechanism based on linked cavity configuration of the basal water conduit system, J. Geophys. Res., 92(B9), 9083-9100.

Kamb, B., C. F. Raymond, W. D. Harrison, H. Engelhardt, K. A. Echelmeyer, N. Humphrey, M. M. Brugman, and T. Pfeffer (1985), Glacier surge mechanism: 1982-1983 surge of variegated Glacier, Alaska, Science, 227(4686), 469-479.

Lewis, S. M., and L. C. Smith (2009), Hydrologic drainage of the Greenland Ice Sheet, Hydrolog. Process., 23(14), 2004-2011.

Lliboutry, L. (1968), General theory of subglacial cavitation and sliding of temperate glaciers, J. Glaciol., 7(49), 21-58.

Mair, D., P. Nienow, M. J. Sharp, T. Wohlleben, and I. Willis (2002), Influence of subglacial drainage system evolution on glacier surface motion: Haut Glacier d'Arolla, Switzerland, J. Geophys. Res., 107(B8), 2175, doi:10.1029/2001JB000514.

Mair, D., I. Willis, U. H. Fischer, B. Hubbard, P. Nienow, and A. Hubbard (2003), Hydrological controls on patterns of surface, internal and basal motion during three "spring events": Haut Glacier d'Arolla, Switzerland, J. Glaciol., 49(167), 555-567.

Nienow, P. W., M. Sharp, and I. C. Willis (1996), Velocity-discharge relationships derived from dye tracer experiments in glacial meltwaters: Implications for subglacial flow conditions, Hydrolog. Process., 10(10), 1411-1426.
Nienow, P., M. Sharp, and I. Willis (1998), Seasonal changes in the morphology of the subglacial drainage system, Haut Glacier d'Arolla, Switzerland, Earth Surf. Proc. Landforms, 23(9), 825-843.

Palmer, S., A. Shepherd, P. Nienow, and I. Joughin (2011), Seasonal speedup of the Greenland Ice Sheet linked to routing of surface water, Earth Planet. Sci. Lett., 302(3-4), 423-428.

Pimentel, S., and G. E. Flowers (2011), A numerical study of hydrologically driven glacier dynamics and subglacial flooding, Proc. R. Soc. A, 467 (2126), 537-558.

Rignot, E., and P. Kanagaratnam (2006), Changes in the velocity structure of the Greenland ice sheet, Science, 311(5763), 986-990.

Röthlisberger, H., and H. Lang (1987), Glacial Hydrology, in Glacio-fluvial Sediment Transfer, edited by A. M. Gurnell and M. J. Clark, John Wiley and Sons, New York.

Schoof, C. (2010), Ice-sheet acceleration driven by melt supply variability, Nature, 468(7325), 803-806.

Schuler, T. V., and U. H. Fischer (2009), Modeling the diurnal variation of tracer transit velocity through a subglacial channel, J. Geophys. Res., 114, F04017, doi:10.1029/2008JF001238.

Schuler, T., U. H. Fischer, and G. H. Gudmundsson (2004), Diurnal variability of subglacial drainage conditions as revealed by tracer experiments, J. Geophys. Res., 109, F02008, doi:10.1029/2003JF000082.

Seaberg, S. Z., J. Z. Seaberg, R. L. Hooke, and D. W. Wiberg (1988), Character of the englacial and subglacial drainage system in the lower part of the ablation area of Storglaciaren, Sweden, as revealed by dye-trace studies, J. Glaciol., 34(117), 217-227.

Sole, A. J., D. W. F. Mair, P. W. Nienow, I. D. Bartholomew, M. A. King, M. J. Burke, and I. Joughin (2011), Seasonal speedup of a Greenland marine-terminating outlet glacier forced by surface melt-induced changes in subglacial hydrology, J. Geophys. Res., 116, F03014, doi:10.1029/ 2010JF001948.

Sundal, A. V., A. Shepherd, P. Nienow, E. Hanna, S. Palmer, and P. Huybrechts (2011), Melt-induced speed-up of Greenland ice sheet offset by efficient subglacial drainage, Nature, 469(7331), 522-583.

Swift, D. A., P. W. Nienow, N. Spedding, and T. B. Hoey (2002), Geomorphic implications of subglacial drainage configuration: rates of basal sediment evacuation controlled by seasonal drainage system evolution, Sediment. Geol., 149(1-3), 5-19.

van de Wal, R. S. W., W. Boot, M. R. van den Broeke, C. Smeets, C. H. Reijmer, J. J. A. Donker, and J. Oerlemans (2008), Large and rapid melt-induced velocity changes in the ablation zone of the Greenland Ice Sheet, Science, 321(5885), 111-113.

van der Veen, C. J. (2007), Fracture propagation as means of rapidly transferring surface meltwater to the base of glaciers, Geophys. Res. Lett., 34, L01501, doi:10.1029/2006GL028385.

Walder, J. S., and B. Hallet (1979), Geometry of former subglacial water channels and cavities, J. Glaciol., 23, 335-346.

Werder, M. A., T. V. Schuler, and M. Funk (2010), Short term variations of tracer transit speed on alpine glaciers, Cryosphere, 4(3), 381-396.

Willis, I. C., M. J. Sharp, and K. S. Richards (1990), Configuration of the drainage system of Midtdalsbreen, Norway, as indicated by dye-tracing experiments, J. Glaciol., 36(122), 89-101.

Willis, I. C., W. Lawson, I. Owens, B. Jacobel, and J. Autridge (2009), Subglacial drainage system structure and morphology of Brewster Glacier, New Zealand, Hydrolog. Process., 23(3), 384-396.

Zwally, H. J., W. Abdalati, T. Herring, K. Larson, J. Saba, and K. Steffen (2002), Surface melt-induced acceleration of Greenland ice-sheet flow, Science, 297(5579), 218-222. 